\title{
Economic valuation of ecosystem services in Africa
}

\author{
Aya Jamouli $^{1^{*}}$, Khali Allali ${ }^{2}$ \\ ${ }^{1}$ Hassan II Institute of Agronomy and Veterinary Sciences, Rabat, Morocco \\ ${ }^{2}$ National School of Agriculture, Meknes, Morocco
}

\begin{abstract}
Ecosystems provide vital services that improve and support livelihoods and human well-being. Consequently, scientific research on ecosystem services (ES) has increased, over the past two decades globally, as well as in Africa. This study provides an overview of existing economic ES valuation methods in Africa using the Web of Science databases. The results highlighted that South Africa recorded the high number of ES valuation publications. The most evaluated ES category was provisioning then regulating services. In terms of economic valuation methods, the market price was the most popular, followed by the contingent valuation and the choice experiment methods. Recommendations are provided for future research in this filed.
\end{abstract}

\section{Introduction}

Ecosystems provide humans a diversity of services known as "Ecosystem services" [1]. They are generally classified into provisioning services such as food and raw materials, regulating services such as water and climate regulation, supporting services such as soil formation, and cultural services such as recreation and tourism. These categories are linked directly to human well-being $[1,2]$. The benefits provided by ES are crucial in maintaining human survival and contribute to poverty alleviation $[2,3]$. Therefore, The loss and disruption of these services, particularly in rural areas of developing countries [4], can negatively affect human well-being [5].

Africa hosts a high number of Least Developed Countries [6], and more than 50 percent of its rural population depends on ecosystem services [7]. However, the ecosystems of this continent are facing various anthropogenic pressures [8]. Common drivers are rapid population growth, increasing demand for food, water and energy, climate change, and overexploitation [9]. This shows the importance of assessment and valuation of such services in safeguarding and managing the loss of ecosystems $[9,10]$.

Several approaches and methods have been developed [11]. According to [12,13], three main approaches can be distinguished: economic methods for estimating monetary values, biophysical methods for mapping and modeling ES, and socio-cultural methods for understanding social values of ES.

Many studies were conducted to assess and review the valuation of ES at different scales, such as: McDonough et al. [14] at the global scale, Rendon et al. [15] for Europe, Schuhmann and Mahon [16] for the Caribbean, Jiang [17] for China, Pittock et al. and Alamgir [18,19] for Australia, Van den Belt and Blake [20] for New Zealand, and Perez-Verdin et al. [21] for Mexico.

In Africa, several reviews were carried out by Vihervaara et al. [22], Seppelt et al. [23], Martinez-Harms and Balvanera [24], Egoh et al. [25], Crossman et al. [26], and Wangai et al. [27]. However, no study has attempted to review the economic valuation of ES in Africa.

Expressing the value of ES in monetary terms in Africa can help to face the challenge of biodiversity loss through the following two ways [9], [28-31]:

\footnotetext{
*Corresponding author: jamouliaya@gmail.com
} 
-Raise awareness about the relative importance of ES;

-Improve decision making on the use and management of ES.

In this context, we conduct a literature review on the economic valuation of ES in Africa. It summarizes the existing studies of ES research and provides key issues for future research. This study focuses on the publication trend between 2005 and 2019, the methods that are highly used and the ES category that is most frequently performed and with which methods.

\section{Methods}

Based on [32], the search process for our literature review consists of four phases: data collection, selection criteria, content analysis, and statistics analysis (Fig. 1).

\subsection{Data collection}

The ISI Web of Knowledge database (http://www.isiknowledge.com) was used for our data collection search using numerous combining terms: "Ecosystem service*" AND "Africa*" AND (valu* OR "Economic analysis" OR "Monetary assessment") in the titles, the abstracts, and as keywords. We gathered all English academic publications from 2005 to 2019. The starting date was the publication year of The Millennium Ecosystem Assessment (MEA) report [33]. Since then, a significant number of ecosystem services research have been published [12].

This ISI website search allowed us to identify 389 studies over the past 15 years. We suppose that our review covers a majority part of the literature, given that the ISI Web of Science indexes 11,877 major journals from 81 different countries across the world [34].

\subsection{Selection criteria}

The abstracts, titles, and methodology sections of the original database were reviewed to decide the final papers to be considered in our economic valuation of ES in Africa. In this study, we retained only the papers that:

-Were conducted in an African country;

-Provided an ES that can be categorized according to the MEA framework [33];

-Used an economic valuation method.

This set of criteria resulted in 28 scientific articles that were summarized and reviewed in detail (Appendix A lists all case studies with their characteristics).

\subsection{Content analysis}

The content of the 28 ES studies selected was classified according to the following aspects:

-Publication year;

-Geographic location;

-Ecosystem type;

-Ecosystem service category;

-Economic valuation method.

\subsection{Statistics analysis}

Descriptive statistics was used in the statistical analysis of the information collected. The results are, generally, organized and presented as a number of case studies and publications for each feature mentioned above. All analysis and graphs were conducted using Excel software. Geographic distributions of economic valuation studies were mapped using ESRI ArcGIS 10.7. 


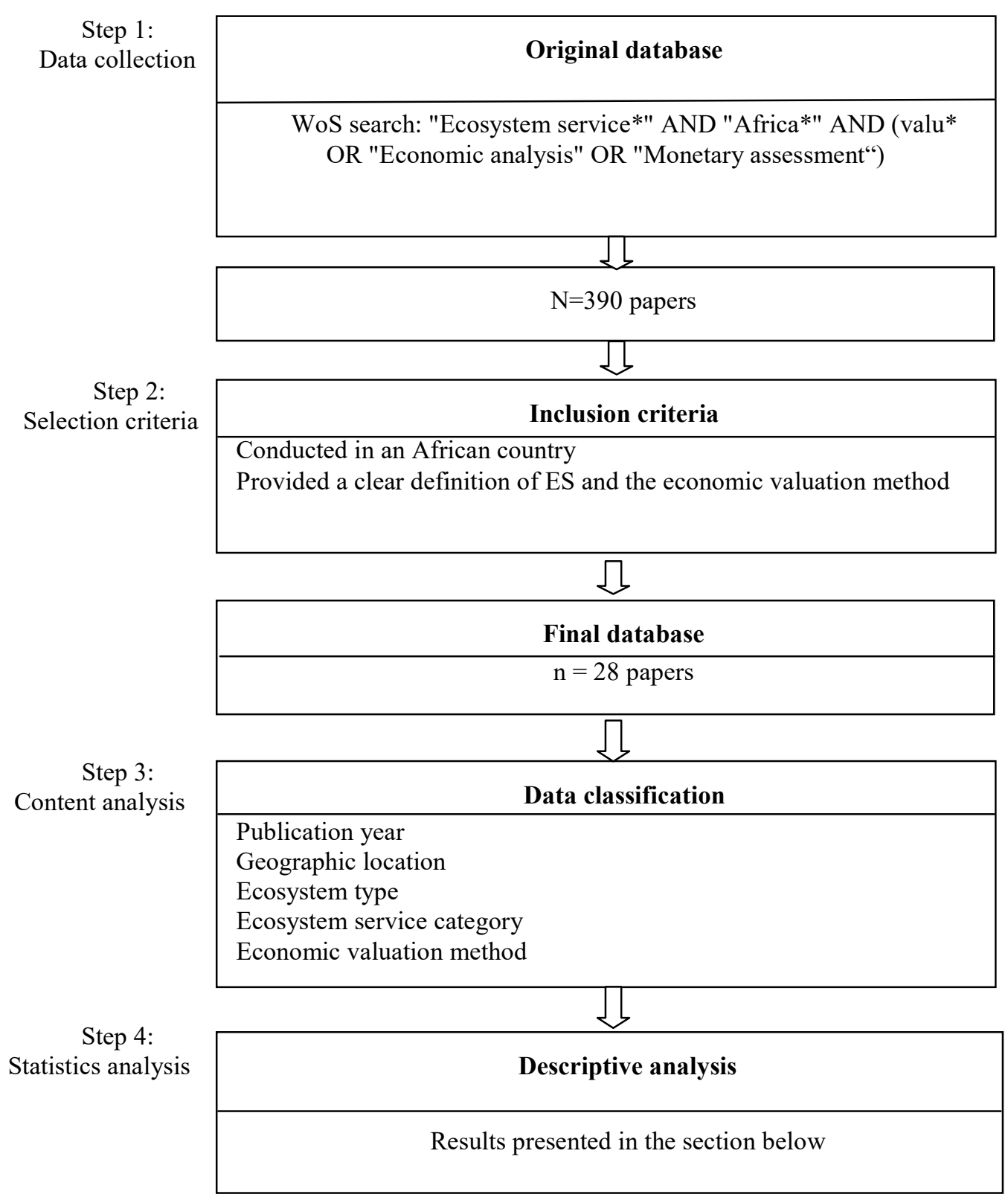

Fig. 1. Steps of the literature review

\section{Results and discussion}

\subsection{Publication trends}

The results show an increase trend in the number of publications since 2012 (Fig. 2). An average of one publication per year was noticed from 2005 to 2012, and it increases to an average of three 
publications per year after 2012. No publication has been selected for 2005, 2006, and 2009. This global progress can be explained by the release of several initiatives and projects around ES and biodiversity, including the Millennium Ecosystem Assessment (MEA), The Economics of Ecosystems and Biodiversity (TEEB), Intergovernmental Platform on Biodiversity and Ecosystem Services (IPBES), and the Ecosystem Services Partnership (ESP). They provide crucial information on the ES concept and attract significant attention of the researches from all over the world [12], [35], including Africa.

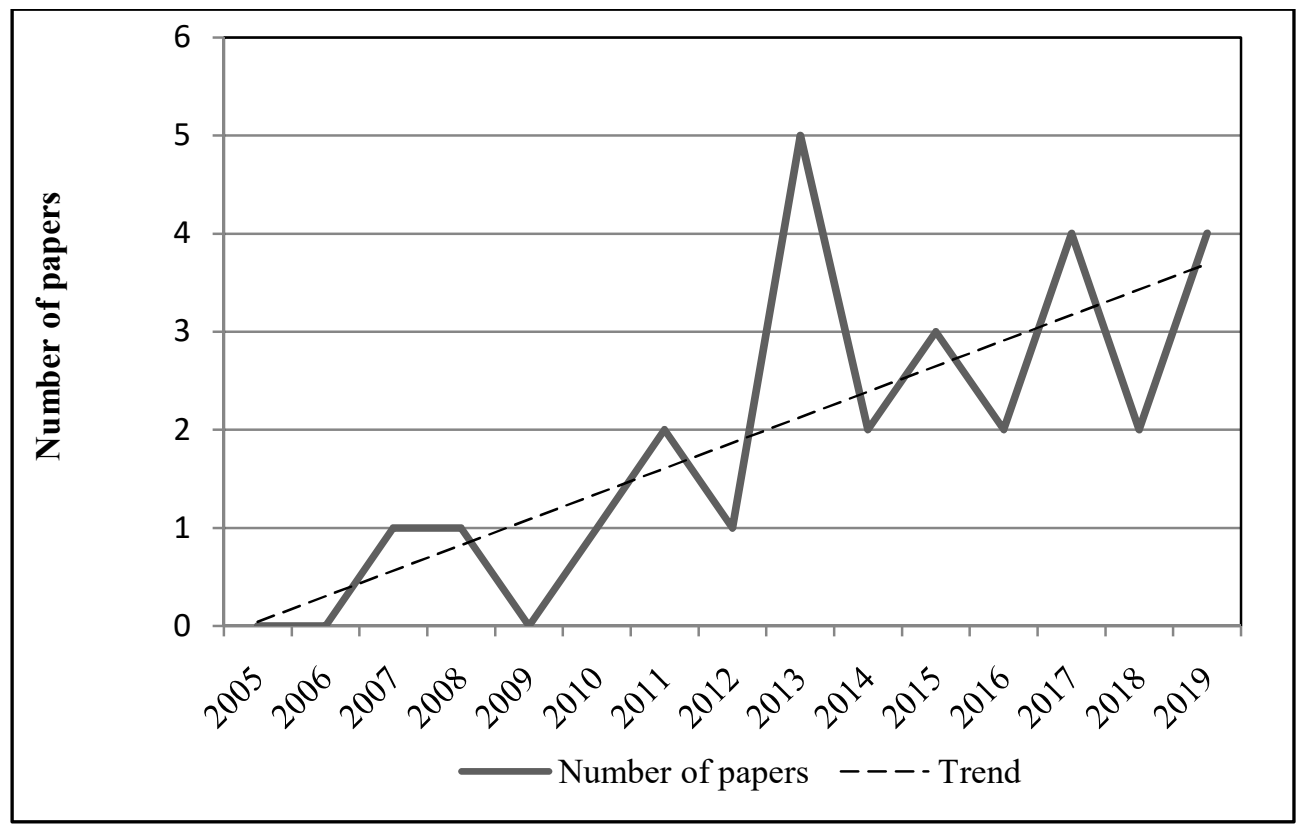

Fig. 2. Number of studies per year between 2005 and 2019

\subsection{Geographical distribution}

As illustrated in Fig. 3, the spatial distribution of economic ES studies shows that more than 50\% of the studies have been conducted in South Africa and Kenya alone (13 and 6, respectively). The remaining papers are distributed between Mozambique, with a total of four studies; Tanzania, with three publications and a single study per country for Senegal, Ghana, Madagascar, and Benin. The first African study related to ES issues was conducted in South Africa in 2005, using a spatial mapping of provisioning and supporting ES [27]. Since then, it has become the leading African country in terms of ES articles published between 1987 and 2017 [36].

Moreover, Southern and Eastern Africa gather almost all case studies, while there were no papers from the northern part of the continent, even in the review provided by [27]. Although it is difficult to explain the lack of research in these countries, it might be due to the limited human and financial resources or the exclusion of non-English studies [37]. 


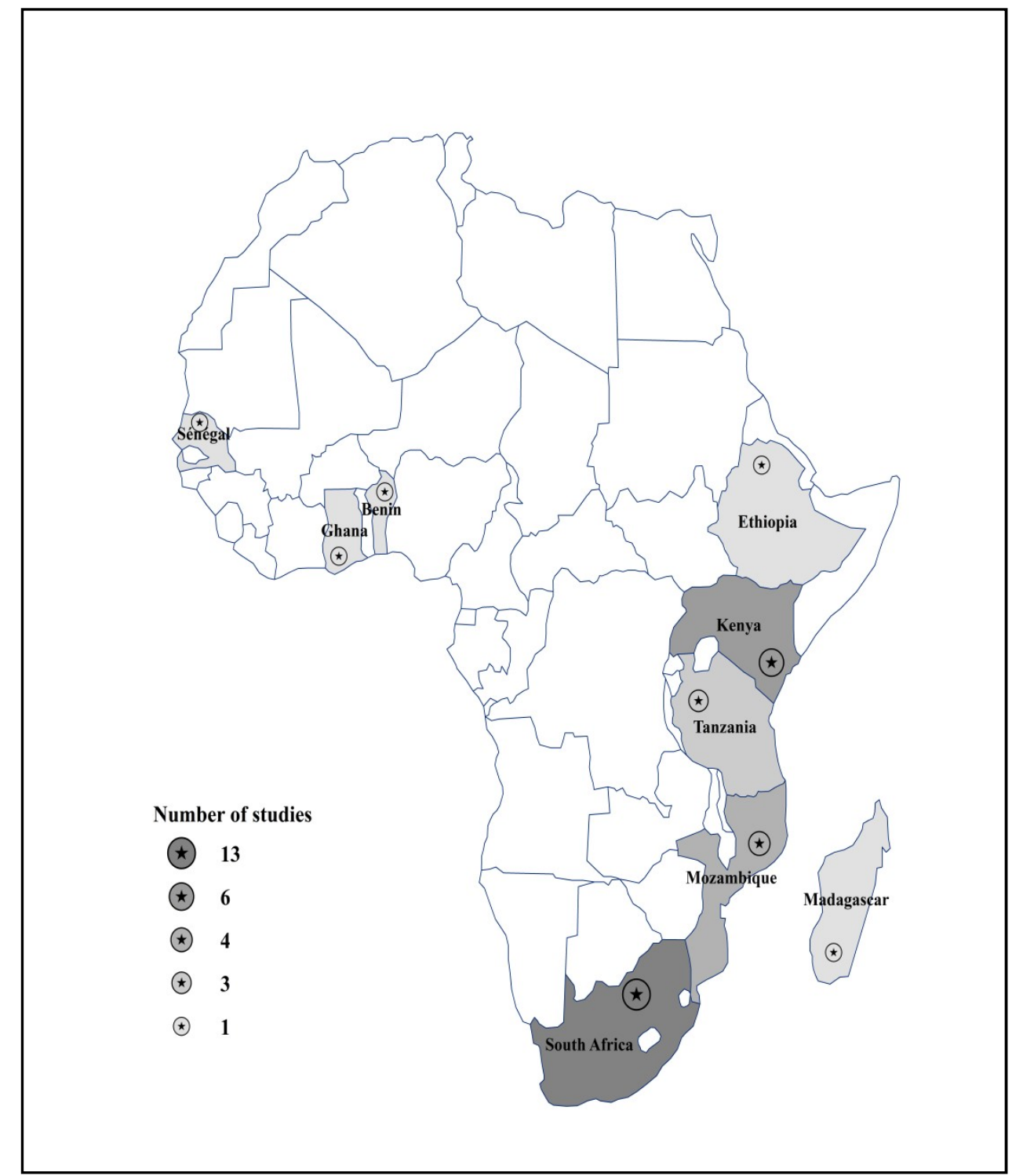

Fig. 3. Geographic distribution of ES studies in Africa (there can be more than one country per study)

\subsection{Ecosystem types}

Within the 28 publications, eight ecosystem types were investigated (Fig. 4). The most dominant types were wetland and forest ecosystems (5 studies for each), followed by marine, agroecosystem, and urban ( 3 studies for each). Freshwater and dryland are also considered ( 2 studies for each). The rest of the studies cover more than one ecosystem (e.g., Grassland, woodland, wetland). However, one study [38] did not clearly define the type of ecosystem and it uses the geographical name of a region (The Orange River Basin in the Lesotho Highlands).

We should note that some ecosystems are difficult to classify. For example, the urban forest is not clear whether to be categorized into a forest or an urban ecosystem. Consequently, future 
studies should adopt an international framework for a consistent definition of ecosystems (e.g., MEA or TEEB) [17].

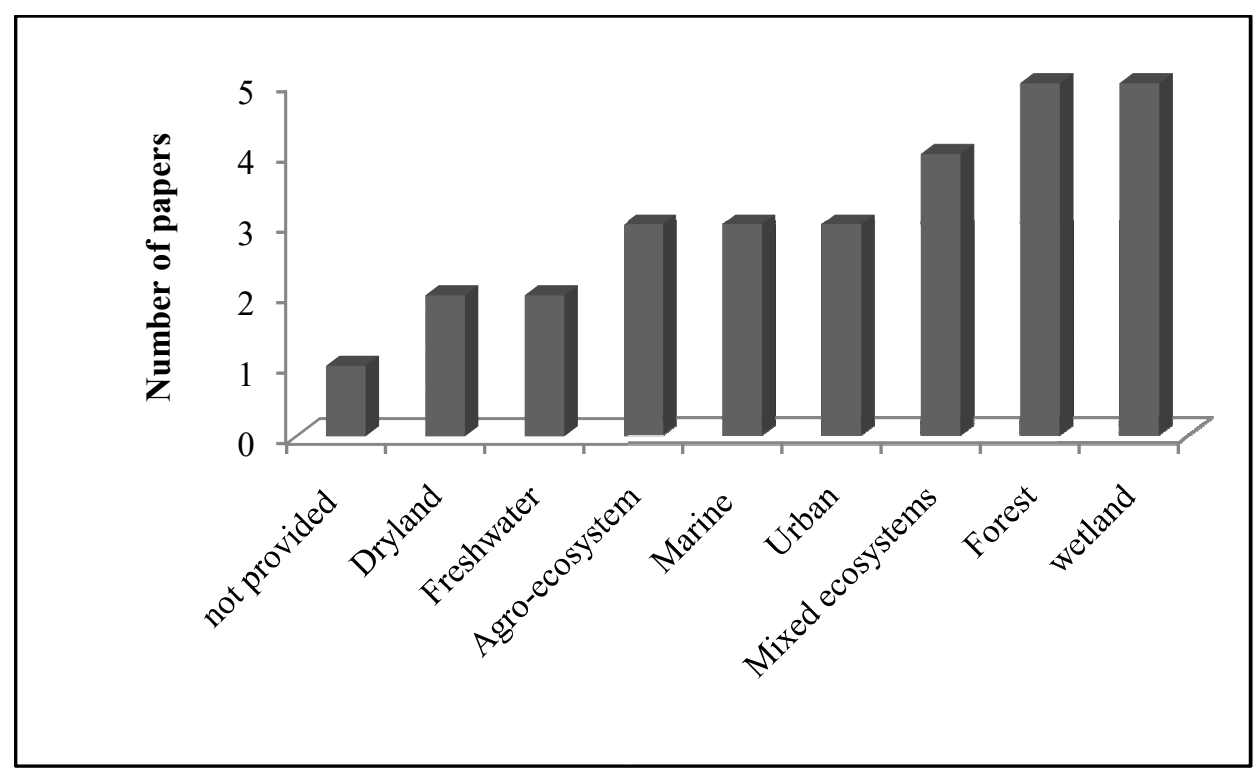

Fig. 4. Number of studies per ecosystem types

\subsection{Ecosystem services categories}

In terms of ecosystem services studied (Fig. 5), provisioning services were the most assessed (13), followed by regulating (12) and cultural services (11). However, supporting services received the least attention from researches (2).

Overall, 19 of 28 studies assessed only a single ES. The remaining nine studies examined multiple services, of which the combination of provisioning and regulating services was the most common. [39] and [40] applied trade-offs and synergies between different types of ES. However, this type of analysis was lacking in those studies based on one category.

Regardless of the number of ES, more than half of the 82 ES categories are provisioning services (food, water, raw materials, etc.), confirming the findings by [27], [36] who reported that provisioning ES were the most services studied. This particular attention can be explained by the fact that many African countries depend directly on this category of services to meet their basic needs [25], [41-43]. 


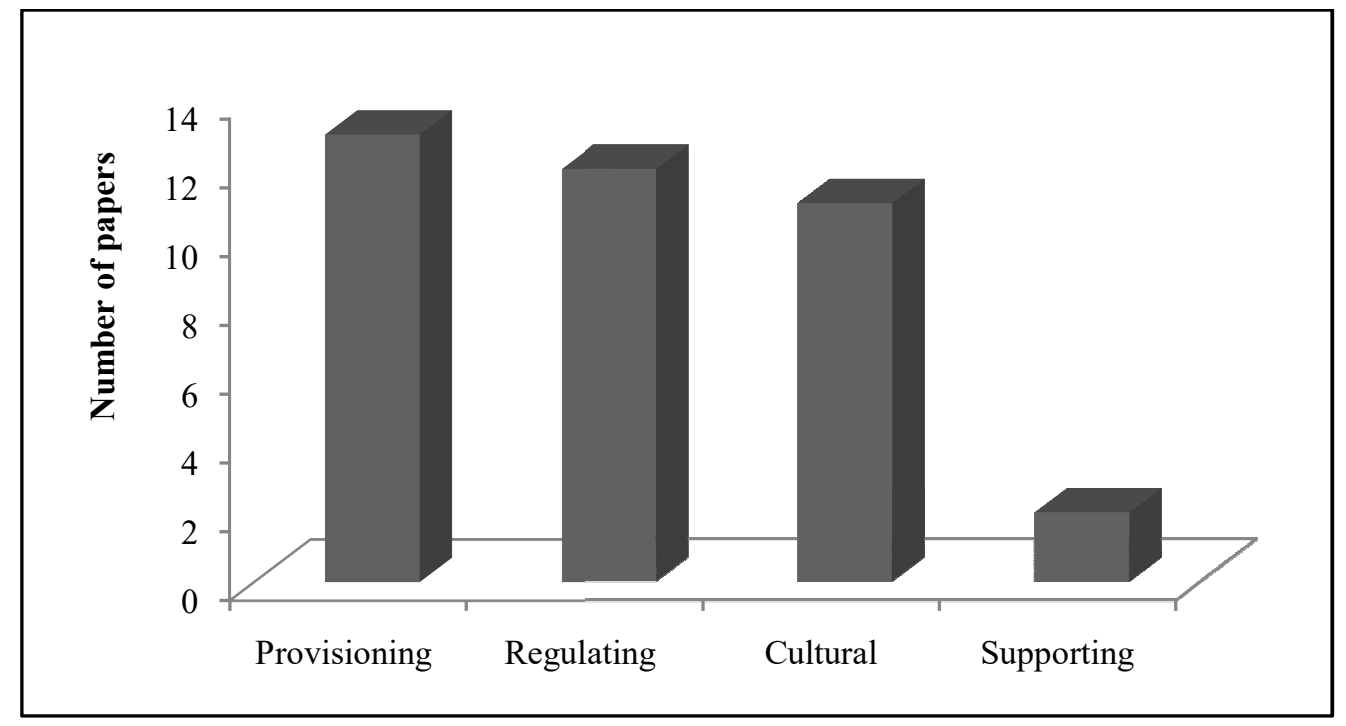

Fig. 5. Number of studies per ES category

\subsection{Economic valuation methods}

This study identified nine main valuation methods, which include revealed and stated preferences (Table 1). The number of papers using each method is shown in Fig. 6. In general, the market price is the most used, followed by the contingent valuation and the choice experiment (used at a similar frequency). The number of ES categories by each economic method is shown in Fig.7. Choice experiment and benefits transfer were applied to assess large categories of services compared to the other methods. In contrast to [44], [45], the market price method has been frequently used to evaluate the provisioning services.

The next sections focus on presenting two of the most used methods per approach.

Table 1. Summary of the reviewed economic valuation methods

\begin{tabular}{|l|l|l|}
\hline Approach & Method & Description from reviewed studies \\
\hline \multirow{4}{*}{$\begin{array}{l}\text { Revealed } \\
\text { preference }\end{array}$} & $\begin{array}{l}\text { Derives economic values of ES using } \\
\text { prices in markets. }\end{array}$ \\
\cline { 2 - 3 } & Production function & $\begin{array}{l}\text { Relates the marketed output to the inputs } \\
\text { used in production. Ecosystem service is } \\
\text { considered as an additional input. }\end{array}$ \\
\cline { 2 - 3 } & Replacement cost & $\begin{array}{l}\text { Uses costs as a proxy for the value of ES, } \\
\text { including methods based on the costs to } \\
\text { substitute services, the costs of avoiding } \\
\text { damages, or the travel and time costs for } \\
\text { access to ecosystems. }\end{array}$ \\
\cline { 2 - 3 } Avoided cost & $\begin{array}{l}\text { Estimates economic values of ES using } \\
\text { the prices of similar properties, usually a } \\
\text { house. }\end{array}$ \\
\cline { 2 - 3 } & Hedonic pricing & $\begin{array}{l}\text { Transfers ES values from existing benefits } \\
\text { from the literature to another context. }\end{array}$ \\
\cline { 2 - 3 } & Benefits transfer &
\end{tabular}




\begin{tabular}{|l|l|l|}
\hline \multirow{2}{*}{ Stated preference } & $\begin{array}{l}\text { Contingent } \\
\text { valuation }\end{array}$ & $\begin{array}{l}\text { Asks people their willingness to pay } \\
\text { (WTP) for specific ES. }\end{array}$ \\
\cline { 2 - 3 } & Choice experiment & $\begin{array}{l}\text { Asks people to choose between a set of } \\
\text { attributes. }\end{array}$ \\
\hline
\end{tabular}

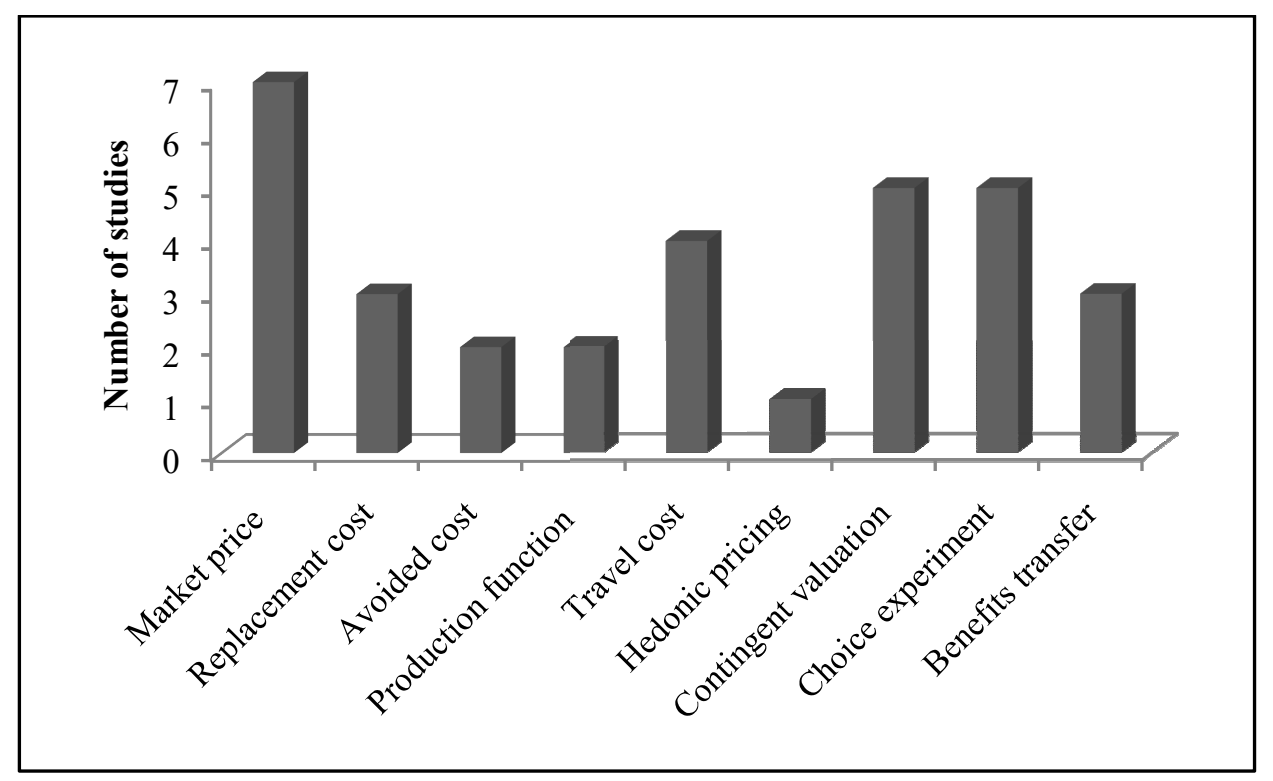

Fig. 6. Number of studies per economic valuation method

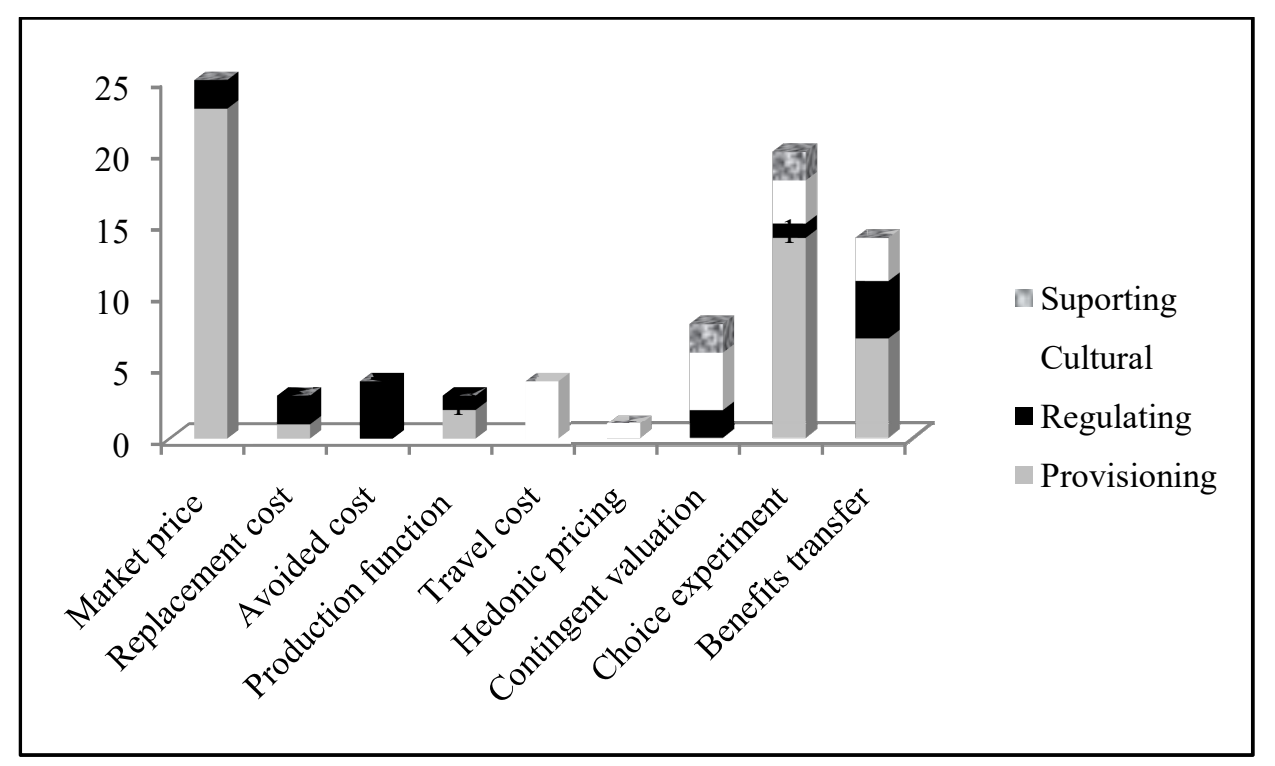

Fig. 7. Number of studies per methods and ESs categories 


\subsubsection{Revealed preference methods}

Seven revealed preference methods, found in seven studies, were identified, of which the market price dominates the database (Table 1, Fig. 6). It directly provides the value of services from markets [46], [47]. For example, [48] calculated the value of grazing service based on the commercial value of the grass. In addition, four papers adopted the travel cost method to provide the value of recreational activities. As an example, to estimate the recreational value of a freshwater system, [49] calculated the time it takes to get to the site and the time spent there.

\subsubsection{Stated preference methods}

Contingent valuation and choice experiment are the two stated preference methods founded (Table 1, Fig. 6). The contingent valuation measures people's willingness to pay (or to accept) [50]. For instance, this method was used to estimate the economic value of non-market benefits of an urban forest in Ghana [51]. Furthermore, choice experiment asks respondents to choose their preferred option between different attributes [9]. [52] investigated the Mozambique population' preferences for water, firewood, and land, applying the choice experiment method. Therefore, stated preference methods had received more attention than the revealed preference methods. This result is consistent with [45], [53].

\subsubsection{Combination of methods}

Four case studies used a combination of economic methods. For example, the ES valuation of [39] was based on market pricing and benefit transfer methods. We also found that three studies used economic and mapping methods. For instance, [54] combined economic valuation (market price and benefit transfer) and mapping assessment to provide the values of key northern Mozambique's marine ecosystem. Integration of economic and biophysical models needs also to be considered as in $[55]$.

\subsection{Limits of the review}

This study was limited to English peer-reviewed studies and it is based exclusively on the databases of the Web of Science. Thus, all conclusions presented here should be interpreted with caution.

\section{Conclusion}

The main objectives of this study were to present an overview of economic valuation of ES in Africa and to offer some recommendations for future research. Twenty eight studies conducted in different parts of the continent were analyzed. Most the studies was conducted in South Africa and focused on services provided by wetland and forest ecosystems. Provisioning services was the most assessed category and the market price was the frequently cited method.

Recommendations for future research on ES in Africa should:

-Improve the knowledge of ES and their incorporation into decision-making and the management of natural resources;

-Combine multidisciplinary approaches, especially economic and mapping methods;

-Explore trade-offs and synergy between different ES;

-Adopt an international framework for a solid classification of ES; 
-Assign equal attention to different ES category, especially those that are neglected (e.g., cultural diversity, knowledge);

-Conduct further economic valuation studies in Africa, especially in the northern region of the continent using English language.

\section{Acknowledgements}

This research is part of a PhD work funded by CNRST (National Center of Scientific Research, Morocco), Pr.Laghfiri Malaynine is acknowledged for his helpful suggestions.

\section{References}

1. M. A. Board, Millennium ecosystem assessment, Washington, DC New Isl, 13 (2005)

2. H. Suich, C. Howe, G. Mace, Ecosystem services and poverty alleviation: a review of the empirical links, Ecosyst. Serv, 12, 137-147 (2015)

3. J.A. Fisher, G. Patenaude, K. Gir, K. Lewis, P. Meir, P. Pinho, M.D. Rounsevell, M. Williams, Understanding the relationships between ecosystem services and poverty alleviation: a conceptual framework, Ecosyst. Serv, 7, 34-45 (2014)

4. H. Tallis, P. Kareiva, M. Marvier, A. Chang, An ecosystem services framework to support both practical conservation and economic development, Proc. Natl. Acad. Sci, 105, 9457-9464 (2008)

5. M. Erhard, A. Teller, J. Maes, A. Meiner, P.M. Berry, A. Smith, R. Eales, L. Papadopoulou, A. Bastrup-Birk, E. Ivits, Mapping and assessment of ecosystems and their services: mapping and assessing the condition of Europe's ecosystems: progress and challenges, (2016)

6. UNDP, Human development report 2019: beyond income, beyond averages, beyond today, United Nations Dev. Progr, 352 (2019)

7. E. Archer, L. Dziba, K.J. Mulongoy, M.A. Maoela, M. Walters, R.O. Biggs, M.C.C. Salem, F. DeClerck, M.C. Diaw, A.E. Dunham, O. Failler, The regional assessment report on biodiversity and ecosystem services for Africa: summary for policymakers, IPBES (2018)

8. J. Hugé, A.J. Rochette, S. de Béthune, C.P. Paitan, K. Vanderhaegen, T. Vandervelden, S. Van Passel, M.P.M. Vanhove, B. Verbist, D. Verheyen, T. Waas, Ecosystem services assessment tools for African Biosphere Reserves: A review and user-informed classification, Ecosyst. Serv, 42, 101079 (2020)

9. M. Masiero, D. Pettenella, M. Boscolo, S. . Barua, I. Animon, J.R. Matta, Valuing forest ecosystem services A training manual for planners and project developers. Forestry Working Paper, Licence: CC BY-NC-SA 3.0 IGO (2019)

10. F. Eigenbrod, B.J. Anderson, P.R. Armsworth, A. Heinemeyer, S.F. Jackson, M. Parnell, C.D. Thomas, K.J. Gaston, Ecosystem service benefits of contrasting conservation strategies in a human-dominated region, Proc. R. Soc. B Biol. Sci, 276, 2903-2911 (2009)

11. K.J. Bagstad, D.J. Semmens, S. Waage, R. Winthrop, A comparative assessment of decision-support tools for ecosystem services quantification and valuation, Ecosyst. Serv, 5, 27-39 (2013)

12. R. Costanza, R. De Groot, L. Braat, I. Kubiszewski, L. Fioramonti, P. Sutton, S. Farber, M. Grasso, Twenty years of ecosystem services: How far have we come and how far do we still need to go?, Ecosyst. Serv, 28, 1-16 (2017)

13. P.A. Harrison, R. Dunford, D.N. Barton, E. Kelemen, B. Martín-López, L. Norton, M. Termansen, H. Saarikoski, K. Hendriks, E. Gómez-Baggethun, B. Czúcz, 
Selecting methods for ecosystem service assessment: A decision tree approach, Ecosyst. Serv, 29, 481-498 (2018)

14. K. McDonough, S. Hutchinson, T. Moore, J. M.S. Hutchinson, Analysis of publication trends in ecosystem services research, Ecosyst. Serv, 25, 82-88 (2017)

15. P. Rendon, M. Erhard, J. Maes, B. Burkhard, Analysis of trends in mapping and assessment of ecosystem condition in Europe, Ecosyst. People, 15, 156-172 (2019)

16. P.W. Schuhmann, R. Mahon, The valuation of marine ecosystem goods and services in the Caribbean: A literature review and framework for future valuation efforts, Ecosyst. Serv, 11, 56-66 (2015)

17. W. Jiang, Ecosystem services research in China: A critical review, Ecosyst. Serv, 26, 10-16 (2017)

18. J. Pittock, S. Cork, S. Maynard, The state of the application of ecosystems services in Australia, Ecosyst. Serv, 1, 111-120 (2012)

19. M. Alamgir, P.L. Pert, S.M. Turton, A review of ecosystem services research in Australia reveals a gap in integrating climate change and impacts on ecosystem services, Int. J. Biodivers. Sci. Ecosyst. Serv. Manag, 10, 112-127 (2014)

20. M. Van Den Belt, D. Blake, Ecosystem services in new Zealand agro-ecosystems: A literature review, Ecosyst. Serv, 9, 115-132 (2014)

21. G. Perez-Verdin, E. Sanjurjo-Rivera, L. Galicia, J.C. Hernandez-Diaz, V. Hernandez-Trejo, M.A. Marquez-Linares, Economic valuation of ecosystem services in Mexico: Current status and trends, Ecosyst. Serv, 21, 6-19 (2016)

22. P. Vihervaara, M. Rönkä, M. Walls, Trends in ecosystem service research: early steps and current drivers, Ambio, 39, 314-324 (2010)

23. R. Seppelt, C.F. Dormann, F.V Eppink, S. Lautenbach, S. Schmidt, A quantitative review of ecosystem service studies: approaches, shortcomings and the road ahead, J. Appl. Ecol, 48, 630-636 (2011)

24. M.J. Martínez-Harms, P. Balvanera, Methods for mapping ecosystem service supply: a review, Int. J. Biodivers. Sci. Ecosyst. Serv. Manag, 8, 17-25 (2012)

25. B.N. Egoh, P.J. O'Farrell, A. Charef, L.J. Gurney, T. Koellner, H.N. Abi, M. Egoh, L. Willeme, An African account of ecosystem service provision: Use, threats and policy options for sustainable livelihoods, Ecosyst. Serv, 2, 71-81 (2012)

26. N.D. Crossman, B. Burkhard, S. Nedkov, L. Willemen, K. Petz, I. Palomo, E.G. Drakou, B. Martín-Lopez, T. McPhearson, K. Boyanova, R. Alkemade, A blueprint for mapping and modelling ecosystem services, Ecosyst. Serv, 4, 4-14 (2013)

27. P.W. Wangai, B. Burkhard, F. Müller, A review of studies on ecosystem services in Africa, Int. J. Sustain. Built Environ, 5, 225-245 (2016)

28. M.T. Ahmed, The Grand Ethiopian Renaissance Dam and the sustainability of water resources: would monetary compensation warrant some more restrictions on dams?, Sustain. Water Resour. Manag, 5, 1327-1334 (2019)

29. LUC, Calculating the economic values of the ecosystem services provided by Natura 2000 features and sites in Wales Prepare, Ecosyst. Serv. Contract, March, 21 (2015)

30. DEFRA, An introductory guide to valuing ecosystem services (2007)

31. P. Kumar, The economics of ecosystems and biodiversity: ecological and economic foundations. UNEP/Earthprint (2010)

32. D.P. Andrew Booth, Anthea Sutton, Systematic approaches to a successful literature review. Los Angeles, London, New Delhi, Singapore, Washington D.C (2012)

33. M. E. Assessment, A report of the Millennium Ecosystem Assessment, Ecosyst. Hum. Well-Being Desertif. Synth, 26 (2005)

34. Clarivate Analytics. Journal Citation Reports (2019) 
35. K. McDonough, S. Hutchinson, T. Moore, J. M.S. Hutchinson, Analysis of publication trends in ecosystem services research, Ecosyst. Serv, 25, 82-88 (2017)

36. X. Zhang, R.C. Estoque, H. Xie, Y. Murayama, M. Ranagalage, Bibliometric analysis of highly cited articles on ecosystem services, PLoS One, 14, 1-16 (2019)

37. L. Neimann Rasmussen, P. Montgomery, The prevalence of and factors associated with inclusion of non-English language studies in Campbell systematic reviews: A survey and meta-epidemiological study, Syst. Rev, 7, 1-12 (2018)

38. G.M. Lange, E. Mungatana, R. Hassan, Water accounting for the Orange River Basin: An economic perspective on managing a transboundary resource, Ecol. Econ., 61, 660-670 (2007)

39. C.A.K. Baba, J. Hack, Economic valuation of ecosystem services for the sustainable management of agropastoral dams. A case study of the Sakabansi dam, northern Benin, Ecol. Indic, 107, 105648 (2019)

40. S. Silvestri, L. Zaibet, M.Y. Said, S.C. Kifugo, Valuing ecosystem services for conservation and development purposes: A case study from Kenya, Environ. Sci. Policy, 31, 23-33 (2013)

41. M. Niamir, Community forestry: herders' decision-making in natural resources management in arid and semi-arid Africa, Community For. herders' Decis. Nat. Resour. Manag. Arid semi-arid Africa (1990)

42. G. Davies, Bushmeat and international development, Conserv. Biol, 16, 587-589 (2002)

43. M. Karki, S.S. Sellamuttu, S. Okayasu, W. Suzuki, L.A. Acosta, Y. Alhafedh, J.A. Anticamara, A.G Ausseil, K. Davies, A. Gasparatos, H. Gundimeda, The regional assessment report on biodiversity and ecosystem services for Asia and the Pacific: summary for policymakers (2018)

44. V.C.S. Hackbart, G.T.N. P. de Lima, R.F. dos Santos, Theory and practice of water ecosystem services valuation: Where are we going?, Ecosyst. Serv, 23, 218-227 (2017)

45. M. Browne, G. Fraser, J. Snowball, Economic evaluation of wetland restoration: a systematic review of the literature, Restor. Ecol, 26, 1120-1126 (2018)

46. De Groot, Function-analysis and valuation as a tool to assess land use conflicts in planning for sustainable, multi-functional landscapes, Landsc. Urban Plan, 75, 175-186 (2006)

47. M. Chaikumbung, H. Doucouliagos, H. Scarborough, The economic value of wetlands in developing countries: A meta-regression analysis, Ecol. Econ, 124, 164-174 (2016)

48. S. Mudavanhu, J. Blignaut, N. Stegmann, G. Barnes, W. Prinsloo, A. Tuckett, The economic value of ecosystem goods and services: The case of Mogale's Gate Biodiversity Centre, South Africa, Ecosyst. Serv, 26, 127-136 (2017)

49. T. Vundla, J. Blignaut, D. Crookes, Aquatic weeds : to control or not to control. the case of the Midmar Dam, KwaZulu-Natal, South Africa, 12, 412-429 (2017)

50. V. Ginsburgh, Contingent valuation, willingness to pay, and willingness to accept, in Economic ideas you should forget, Springer, 65-66 (2017)

53. W.K. Dumenu, What are we missing? Economic value of an urban forest in Ghana, Ecosyst. Serv, 5, 137-142 (2013)

52. A.K. Kosenius, M. Kniivilä, M. Pitiot, P. Horne, Location of forest plantations in Mozambique: Gains and losses in water, firewood and land availability, Land use policy, 88, 104175 (2019)

53. X. Cheng, S. Van Damme, L. Li, P. Uyttenhove, Evaluation of cultural ecosystem services: A review of methods, Ecosyst. Serv, 37, 100925 (2019)

54. A. Ghermandi, D. Obura, C. Knudsen, P.A.L.D. Nunes, Marine ecosystem services 
in the Northern Mozambique Channel: A geospatial and socio-economic analysis for policy support, Ecosyst. Serv, 35, 1-12 (2019)

55. B.L. Keeler, S. Polasky, K.A Brauman, K.A. Johnson, J.C. Finlay, A. O’Neill, K. Kovacs, B. Dalzell, Linking water quality and well-being for improved assessment and valuation of ecosystem services, Proc. Natl. Acad. Sci, 109, 18619-18624 (2012)

56. B. Tibesigwa, J. Siikamäki, R. Lokina, J. Alvsilver, Naturally available wild pollination services have economic value for nature dependent smallholder crop farms in Tanzania, Sci. Rep, 9, 1-10 (2019)

57. K. Bekele, J. Haji, B. Legesse, U. Schaffner, Economic impacts of Prosopis spp. invasions on dryland ecosystem services in Ethiopia and Kenya: Evidence from choice experimental data, J. Arid Environ, 158, 9-18 (2018)

58. M. Jacobson, Y.H. Shr, F. Dalemans, C. Magaju, R. Ciannella, Using a choice experiment approach to assess production tradeoffs for developing the croton value chain in Kenya, For. Policy Econ, 86, 76-85 (2018)

59. J. Dikgang, E. Muchapondwa, Local communities' valuation of environmental amenities around the Kgalagadi Transfrontier Park in Southern Africa, J. Environ. Econ. Policy, 6, 168-182 (2017)

60. S. Niquisse, P. Cabral, Assessment of changes in ecosystem service monetary values in Mozambique, Environ. Dev, 25, 12-22 (2018)

61. A. Seck, A dichotomous-choice contingent valuation of the Parc Zoologique de Hann in Dakar, African J. Agric. Resour. Econ, 11, 226-238 (2016)

62. M.C. Mutoko, L. Hein, C. A. Shisanya, Tropical forest conservation versus conversion trade-offs: Insights from analysis of ecosystem services provided by Kakamega rainforest in Kenya," Ecosyst. Serv, 14, 1-11 (2015)

63. C.A.K. Daly, G. Fraser, J. D. Snowball, Willingness to pay for marine-based tourism in the Ponta do Ouro Partial Marine Reserve, Mozambique, African J. Mar. Sci, 37, 33-40 (2015)

64. J. Cilliers, S. Cilliers, From green to gold: a South African example of valuing urban green spaces in some residential areas in Potchefstroom, T. Reg. Plan, 2015, 1-12 (2015)

65. J. Bayliss, M. Schaafsma, A. Balmford, N.D. Burgess, J.M. Green, S.S. Madoffe, S. Okayasu, K.S.H. Peh, P.J. Platts, W.Y. Douglas, The current and future value of nature-based tourism in the Eastern Arc Mountains of Tanzania, Ecosyst. Serv, 8, 75-83 (2014)

66. D.W. Mulatu, A. van der Veen, P.R. van Oel, Farm households' preferences for collective and individual actions to improve water-related ecosystem services: The Lake Naivasha basin, Kenya, Ecosyst. Serv, 7, 22-33 (2014)

67. W.J. De Lange, R. Veldtman, M. H. Allsopp, Valuation of pollinator forage services provided by Eucalyptus cladocalyx, J. Environ. Manage, 125, 12-18 (2013)

68. B. Conradie, M. Garcia, An estimate of the recreational value of the a gulhas plain , south africa, with special reference to the value of plant biodiversity a Data collection, 16, 170-182 (2013)

69. A. Schäffler, M. Swilling, Valuing green infrastructure in an urban environment under pressure - The Johannesburg case, Ecol. Econ, 86, 246-257 (2013)

70. N.A. Davenport, C.M. Shackleton, J. Gambiza, The direct use value of municipal commonage goods and services to urban households in the Eastern Cape, South Africa, Land use policy, 29, 548-557 (2012)

[71] S. Simonit, C. Perrings, Sustainability and the value of the 'regulating' services: Wetlands and water quality in Lake Victoria, Ecol. Econ, 70, 1189-1199 (2011) 
[72] M. du Preez, S. G. Hosking, He value of the trout fishery at Rhodes, North Eastern Cape, South Africa: A travel cost analysis using count data models, J. Environ. Plan. Manag, 54, 267-282 (2011)

73. M. Du Preez, S. Tessendorf, Application of thr contigent valuation method to estimate the willingness to pay for restoring indigenous vegetation in Underberg, Kwazulu-Natal, South Africa, 13 (2010)

74. M.H. Allsopp, W.J. de Lange, R. Veldtman, Valuing insect pollination services with cost of replacement, PLoS One, 3 (2008)

\section{Appendix A}

The 28 studies on the economic valuation of African ES

\begin{tabular}{|c|c|c|c|c|c|c|}
\hline Study & Year & $\begin{array}{l}\text { Country/Area } \\
\text { of study }\end{array}$ & $\begin{array}{l}\text { Type of } \\
\text { Ecosystem }\end{array}$ & $\begin{array}{l}\text { MEA } \\
\text { classification } \\
\text { (No of ES } \\
\text { assessed) }\end{array}$ & $\begin{array}{l}\text { Number } \\
\text { of ES }\end{array}$ & $\begin{array}{l}\text { Valuation } \\
\text { method }\end{array}$ \\
\hline [39] & 2019 & Benin & $\begin{array}{l}\text { Mixed } \\
\text { ecosystem }\end{array}$ & $\begin{array}{l}\text { Provisioning } \\
\text { (7) } \\
\text { Regulating } \\
(2)\end{array}$ & 9 & $\begin{array}{l}\text { Market price } \\
\text { Benefit } \\
\text { transfer }\end{array}$ \\
\hline [56] & 2019 & Tanzania & $\begin{array}{l}\text { Agro- } \\
\text { ecosystem }\end{array}$ & Regulating & 1 & $\begin{array}{l}\text { Production } \\
\text { function }\end{array}$ \\
\hline [54] & 2019 & $\begin{array}{l}\text { Tanzania } \\
\text { Mozambique } \\
\text { Madagascar }\end{array}$ & Marine & $\begin{array}{l}\text { Provisioning } \\
\text { (1) } \\
\text { Regulating } \\
\text { (1) } \\
\text { Cultural (1) }\end{array}$ & 3 & $\begin{array}{l}\text { Market price } \\
\text { Benefit } \\
\text { transfer }\end{array}$ \\
\hline [52] & 2019 & Mozambique & Forest & Provisioning & 2 & $\begin{array}{l}\text { Choice } \\
\text { experiment }\end{array}$ \\
\hline [57] & 2018 & $\begin{array}{l}\text { Ethiopia } \\
\text { Kenya }\end{array}$ & Dryland & $\begin{array}{l}\text { Provisioning } \\
\text { (2) } \\
\text { Cultural (2) } \\
\text { Regulating } \\
\text { (1) }\end{array}$ & 5 & $\begin{array}{l}\text { Choice } \\
\text { experiment }\end{array}$ \\
\hline [58] & 2018 & Kenya & Forest & Provisioning & 1 & $\begin{array}{l}\text { Choice } \\
\text { experiment }\end{array}$ \\
\hline [59] & 2017 & South Africa & $\begin{array}{l}\text { Agro- } \\
\text { ecosystem }\end{array}$ & $\begin{array}{l}\text { Regulating } \\
\text { (1) }\end{array}$ & 1 & $\begin{array}{l}\text { Avoided } \\
\text { cost }\end{array}$ \\
\hline [48] & 2017 & South Africa & $\begin{array}{l}\text { Mixed } \\
\text { ecosystems }\end{array}$ & $\begin{array}{l}\text { Provisioning } \\
\text { (3) } \\
\text { Regulating } \\
\text { (1) }\end{array}$ & 4 & $\begin{array}{l}\text { Production } \\
\text { function } \\
\text { Market } \\
\text { prices }\end{array}$ \\
\hline [60] & 2017 & Mozambique & $\begin{array}{l}\text { Mixed } \\
\text { ecosystems }\end{array}$ & $\begin{array}{l}\text { Provisioning } \\
\text { (7) }\end{array}$ & 9 & $\begin{array}{l}\text { Benefit } \\
\text { transfer }\end{array}$ \\
\hline
\end{tabular}




\begin{tabular}{|c|c|c|c|c|c|c|}
\hline & & & & $\begin{array}{l}\text { Regulating } \\
\text { (1) } \\
\text { Cultural (1) }\end{array}$ & & \\
\hline [49] & 2017 & South Africa & Freshwater & Cultural & 1 & Travel cost \\
\hline [59] & 2016 & South Africa & Dryland & Provisioning & 7 & $\begin{array}{l}\text { Choice } \\
\text { experiment }\end{array}$ \\
\hline [61] & 2016 & Senegal & Forest & Cultural & 1 & $\begin{array}{l}\text { Contingent } \\
\text { valuation }\end{array}$ \\
\hline [62] & 2015 & Kenya & Forest & $\begin{array}{l}\text { Provisioning } \\
\text { (7) } \\
\text { Cultural (2) }\end{array}$ & 9 & $\begin{array}{l}\text { Market Price } \\
\text { Contingent } \\
\text { valuation } \\
\text { Travel cost }\end{array}$ \\
\hline [63] & 2015 & Mozambique & Marine & Cultural & 1 & $\begin{array}{l}\text { Contingent } \\
\text { valuation }\end{array}$ \\
\hline [64] & 2015 & South Africa & Urban & Cultural & 1 & $\begin{array}{l}\text { Hedonic } \\
\text { pricing }\end{array}$ \\
\hline [65] & 2014 & Tanzania & Wetland & Cultural & 1 & $\begin{array}{l}\text { Contingent } \\
\text { valuation }\end{array}$ \\
\hline [66] & 2014 & Kenya & Wetland & $\begin{array}{l}\text { Provisioning } \\
\text { (3) } \\
\text { Cultural (1) } \\
\text { Supporting } \\
\text { (2) }\end{array}$ & 6 & $\begin{array}{l}\text { Choice } \\
\text { experiment }\end{array}$ \\
\hline [67] & 2013 & South Africa & $\begin{array}{l}\text { Agro- } \\
\text { ecosystem }\end{array}$ & Provisioning & 1 & $\begin{array}{l}\text { Replacement } \\
\text { cost }\end{array}$ \\
\hline [68] & 2013 & South Africa & Marine & Recreation & 1 & Travel cost \\
\hline [51] & 2013 & Ghana & Urban & $\begin{array}{l}\text { Regulating } \\
\text { (1) } \\
\text { Supporting } \\
\text { (2) }\end{array}$ & 3 & $\begin{array}{l}\text { Contingent } \\
\text { valuation }\end{array}$ \\
\hline [69] & 2013 & South Africa & Urban & $\begin{array}{l}\text { Regulating } \\
\text { (1) } \\
\text { Cultural (2) }\end{array}$ & 3 & Market price \\
\hline [40] & 2013 & Kenya & Wetland & Provisioning & 2 & Market price \\
\hline [70] & 2012 & South Africa & Urban & Provisioning & 3 & Market price \\
\hline [71] & 2011 & Kenya & $\begin{array}{l}\text { Mixed } \\
\text { ecosystems }\end{array}$ & Regulating & 3 & $\begin{array}{l}\text { Avoided } \\
\text { cost }\end{array}$ \\
\hline [72] & 2011 & South Africa & Freshwater & Cultural & 1 & Travel cost \\
\hline
\end{tabular}




\begin{tabular}{|c|l|l|l|l|c|l|}
\hline$[73]$ & 2010 & South Africa & $\begin{array}{l}\text { Agro- } \\
\text { ecosystem }\end{array}$ & Regulating & 1 & $\begin{array}{l}\text { Contingent } \\
\text { valuation }\end{array}$ \\
\hline$[74]$ & 2008 & South Africa & $\begin{array}{l}\text { Not } \\
\text { provided }\end{array}$ & Regulating & 1 & $\begin{array}{l}\text { Replacement } \\
\text { cost }\end{array}$ \\
\hline$[38]$ & 2007 & South Africa & Wetland & Regulating & 1 & $\begin{array}{l}\text { Replacement } \\
\text { cost }\end{array}$ \\
\hline
\end{tabular}

